\title{
Implication of energy expansion via the interaction of coal, industrialization, and agriculture towards climate goal: dual sustainability analysis
}

\author{
Edmund Ntom Udemba ${ }^{1}$
}

Received: 12 August 2021 / Accepted: 10 November 2021 / Published online: 30 November 2021

(c) The Author(s), under exclusive licence to Springer-Verlag GmbH Germany, part of Springer Nature 2021

\begin{abstract}
This current study seeks to investigate the policy implication of Turkey's recent energy policies on its sustainable development. This study uses Turkey's country-specific data and series of 1974 to 2018 for effective investigation and justification of the findings of this study with emphasis on both short-run and long-run implications. Three models were fitted to achieve study objectives to accommodate both environmental sustainability and economic impacts. Ecological footprint was considered better measure and used as proxy for the environment related model. In summary, with environment models, the selected series (per capita GDP, industrialization, agriculture, coal as a single energy use, and mixed energy use) except per capita $\mathrm{GDP}^{2}$ were found positively and significantly related to ecological footprint in both short run and long run which translates to poor performance of Turkey's environment. Also, using economic growth model, the selected series (industrialization, energy use, and agriculture) were all confirmed positively and significantly related to the economic growth (per capita GDP). Additionally, environmental Kuznets curve (EKC) was established for Turkey's environment and economic performance. Furthermore, using Granger causality as robust check to these findings, a nexus was found among the series confirming the validity of the cointegration (short- and long-run policies) estimations and results. In congruence with literature and hypotheses, the results from cointegration estimation shows that the twin polices may be good to the economic performance but will spark off adverse effect on environment.
\end{abstract}

Keywords Ecological footprint · Twin policies $\cdot$ Coal/energy use $\cdot$ GDP $\cdot$ EKC $\cdot$ Turkey sustainable development

JEL Classification C1 $\cdot \mathrm{C} 32 \cdot \mathrm{E} 6 \cdot \mathrm{L} 7 \cdot \mathrm{O} 4 \cdot \mathrm{Q} 3 \cdot \mathrm{Q} 4 \cdot \mathrm{Q} 5$

\section{Introduction}

Responsible Editor: Roula Inglesi-Lotz

\section{Highlights of Turkey coalpolicies}

- Studied policy implication coal expansion and consolidation of Natural gas in Turkey

- Twin polices enhance Turkey's economic performance

- Twin policies spark off adverse effect on environment

- Nexus was confirmed among $\mathrm{CO}_{2}$, GDP, industrialization, agriculture, coal, and energy use

- Finding supports the environmental Kuznets curve (EKC) hypothesis which is among the theoretical backgrounds of this study

Edmund Ntom Udemba

eudemba@gelisim.edu.tr; eddy.ntom@gmail.com

1 Faculty of Economics Administrative and Social Sciences, Istanbul Gelisim University, Istanbul, Turkey
Turkey has remained a mirror of a fast developing, and emerging country through its industrial exploits and growth. Massive changes such as privatization of many state-owned industries have been witnessed in Turkish economic development. Among the industries mostly affected are banking, communication, and transport industries. With the speed of engulfing into entrepreneurialism, it could be said that Turkey is driving its economy entirely in a new direction. Turkey is considered a connecting link between European and Asian continents because of its strategic location in between the nations. Recently, Turkey is named a hub of industrial and business activities within the Asian and European region. This new economic transformation agenda in industrial and manufacturing has placed Turkey as among the fast growing economies, and it is forecasted that Turkey 
is driving towards becoming one of the 10 largest economies globally in the year 2023 (Yavuz et al. 2013; Monje et al. 2008).

Turkey is on the path of both industrial expansion and sustenance of the trend in industry and economic development. Following the industrial expansion and businesses boom in Turkey, energy remains a very significant factor in fostering the prosperity, economic growth, and development of the country. Turkey's demand for energy is overwhelming which is forecasted to be on increasing trend even in the future (Ediger and Berk, 2011). The country's demand for energy is far greater than its supply. In Turkey's 11th development plan, it is remarked that the country's primary energy demand is expected to increase to $18 \%$ by 2023 beyond 2018 levels. Turkey's energy demand has been on the increase for some decades because of its rapid industrial development with innovational plans (Kilic and Kaya, 2007). This has exposed Turkey into high importation of two major energy sources (Natural gas and Oil) for sustenance of energy generation in the country. In a way to minimize import of primary energy especially hard coal and natural gas, Turkey's authority has initiated the policy of coal expansion and subsidizing of new coal-fired power plants in attempt to increase mining capacity of the country's widespread lignite coalfields (Cardoso and Turhan, 2018). According to the Ministry of Energy and Natural Resources, coal position in the energy mix of Turkey is significant, and its power through burning coal meets a greater percentage of the country's increasing electricity demand. Turkey's fossil fuel energy mix has in its composition $32 \%$ of coal, $37 \%$ of oil, and $31 \%$ of gas. This has great implication to the country's environmental performance. The massive industrial revolution in Turkey has put the country in a crossroad to future of its energy, and has equally awakened the need for energy security for the sustenance of the trend of the economic growth via industrial activities. As at 2017, Turkey's industrial production growth rate was recorded at $9.1 \%$ (CIA World Factbook 2019). In order to cushion the effect of high cost of energy sourcing, Turkey has embarked on a twin policy of coal expansion and maximization of liquified natural gas (LNG) via gas market liberalization. Turkey's sectoral contribution to the 2017 economic performance could be seen in Table 1 with agriculture contributing approximately $7 \%$, industry contributing approximately $32.3 \%$, and service contributing $61 \%$ approximately.

Recently, Turkish government has commenced the process of limiting its over dependency on gas importation through alternative sources (expansion of coal and adoption of renewable energy sources). The policy of coal expansion was conceived by the Turkish authorities in support for energy boosting. The domestically harnessed coal was chosen as the preferred fossil fuel for electricity boosting. Much emphasis has been put on the domestic coal because
Table 1 Turkey's GDP composition by sector

\begin{tabular}{lc}
\hline Sector & $\begin{array}{c}\text { Percentage } \\
\text { contribution }\end{array}$ \\
\hline Agriculture & 6.8 \\
Industry & 32.3 \\
Service & 60.7 \\
Labor force in sectors & \\
$\quad$ Agriculture & 18.4 \\
$\quad$ Industry & 26.6 \\
$\quad$ Service & 54.9 \\
\hline
\end{tabular}

Source: Compiled by author with information from CIA World Factbook (2019)

of its presumed energy security which is considered essential and needful for industrial and economic expansion. This has necessitated doubling of the use of domestic coal for power generation as from 2019. Among the steps taken are the commissioning of two new coal power plants in Turkey in 2018 (Yumus Emre and Can-2), and the Soma Kolin Power Plant with additional capacity of $1.2 \mathrm{GW}$ which resumed operation in June 2019 (Kaya and Tecmen 2011). Sequel to this, the Ministry of Energy and Natural Resources has encouraged coal-fired power plants by holding tenders for domestic coal lignite and this paved way for launching of 1.3 GW Hunutlu thermal power plant in September 2019. According to CoalSwarm, Turkey is ranked the 13th largest fleet of operational coal plants globally with $18 \mathrm{GW}$ coal plants. The vision is to expand this to the tune of $30 \mathrm{GW}$ capacity by 2023 . This policy does not negate the use of natural gas as natural gas has proven to be the highest source of energy to Turkey; rather, it is geared towards mitigating the dependency rate on import of natural gas. Because of Turkish strategic location and the perceived increase on liquefied natural gas (LNG) globally, the country is seriously working towards making the most benefit of the situation. This is in line with Turkish eagerness to become a gas trading hub considering its strategic position among many countries in both Europe and Asia. This, they plan to achieve by developing both storage and regasification capacities in 2023.

However, with the trend of economic expansion via industrial performance and business boom leading to great stake in energy consumption and security, many energy economist and environmentalists around the globe are worried as to environment and climate implication of both industrial revolution and the twin policies (coal expansion and natural gas maximization via gas market liberalization) of Turkish authorities. Following the path of industrialization has its environmental cost, just like any other industrialized economies, Turkey has had to pay an environmental price for its industrialization and economic growth expansion. The twin energy policies (coal expansion and gas maximization) of Turkey for energy security through fossil fuels sources which are known with high 
emitting of air pollution are not unconnected with hampering good environment performance and economic performance. Turkey's emissions have risen significantly over the past decades (CAT 2019). The main sectors contributing to the rise of carbon emissions in Turkey includes industrial sector (industrial processes and product use), agricultural sector (agricultural activities as it includes cash crop farming, fishing, and herders), and waste. These sectors accounted for $73 \%, 13 \%$, and $3.3 \%$ of emissions, respectively. Air pollution is a major problem across Turkey, especially in the urban areas. Statistics from the Ministry of Environment and Urbanization, Turkey, in 2017 shows the ranges of 151 and 200 amount of air pollution in almost every province of Turkey. So many provinces actually have the record of air pollution that exceeds 300 which imply the greater environmental hazard via air pollution. Considering the kind of coal accessed in Turkey, the amount of $\mathrm{CO}_{2}$ emissions in Turkey is on the increasing rate. The share of coal in Turkey's greenhouse gas emissions is accounting to a third of 500 million tons of Turkey's total emissions (Veyisoglu et al. 2016). Cost of coal expansion cut across both the economic and environmental sphere of the country ranging from polluted air, soil to water stressed. Coal production is associated with production of high amount of toxic ashes which are capable of polluting both the air and soil (Waldman and Caliskan 2017). Powering of coal plant is water intensive project due to the application of wet cooling towers, and this increases the water intake for electricity generation (ElKhozondar 2017). This has some economic implications when its impact is considered negative on the agriculture and food products via global warming and shortage of water through water stress (Dudu and Çakmak 2018). In sum, Turkey's environment and climate is fast changing, and the effect will be felt across the country (Reckien et al. (2018): Cardoso and Turhan 2018).

On the premises of Turkey's twin policies of coal expansion and gas trading via storage and regasification because of the country's economic and industrial expansion, author undertakes the investigation of both the economic and environment implications of these policies. Also, because of the industrial expansion following the economic performance of Turkey, the current study seeks to research the impact of the current economic performance through industry on the environment performance of Turkey. This is done by testing EKC for the case of Turkey by applying a non-linear and historical pattern of economic growth (economic growth and squared economic growth) and industry in the model for more and valid findings on the policy implication of coal and gas trading in Turkey. Ecological footprint is utilized in this study in measuring environmental performance because of its content and for a comprehensive detail on the environment performance in Turkey. Other studies (Narayan and Narayan 2010; Pao and Tsai 2011; Akpan and Akpan 2012; Li et al. 2015; Carlson et al. 2017) have in the past adopted carbon $\left(\mathrm{CO}_{2}\right)$ emission and greenhouse gas (GHGs) as the perceived correct proxies to expose the environment performance; however, divergent views from the $\mathrm{CO}_{2}$ and $\mathrm{GHG}$ have considered the ecological footprint (EFP) as the more comprehensive measure of the environmental performance (Rees et al. 1996; Ulucak and Lin 2017). Human activities in the areas of industrialization and agriculture and other businesses impact heavily on energy consumption and these largely contribute to emissions and increase of ecological footprint (Halicioglu 2009; Grimes and Kentor 2003). For this, industrialization and agriculture are considered among the variables in the model because of their importance Turkish economic performance. This study takes on a dual model approach of research to unveil both the environment and economic performance of Turkey under these policies. The study adopts different scientific approaches with different models involving the combination of different fossil fuels (coal, gas, and oil) as the energy use on one model, and coal as a single energy source to measure energy use in other model. This is an attempt to expose the real impact of coal to both environment and economic performance of Turkey. Economic growth model was incorporated in this study for understanding of the nexus among the economic growth, industrial growth, and energy uses towards Turkey's economic performance. Author utilizes different scientific approaches (such as structural break test, short- and long-run Granger causal analysis for forecasting, autoregressive distribution lag (ARDL) in both linear description (with short and long run) and bound testing of cointegration, and diagnostic analysis.) in making sure that maximum insight is ascertained from this study. This is not the first study on the environmental performance of Turkey, but this study differs from the existing works in the following ways: (a) applying two energy sources (groups [oil, gas and coal] and coal) as single energy use; (b) utilization of industrialization as among the variables to test environment; (c) building on economic growth model with nexus among the economic growth, industrialization, and energy use for insight on the Turkey's economic performance; and (d) the application of ecological footprint as the proxy to measure environment in Turkey for a comprehensive understanding of different dynamics of environmental performance.

The rest of this current study is structured as follows: the second section gives a detailed theoretical background of the study. The third, fourth, and fifth sections analyze the methodology, empirical analyses, and conclusion of the paper, respectively.

\section{Literature review}

\section{Empirical review}

In the energy-economic growth and environmental nexus, several studies such as Al-Mulali et al. (2015a, 2015b), Alola et al. (2019), Bagliani et al. (2008), Chen et al. 
(2006), Solarin and Bello (2018), Wang et al. (2008), Kivyiro and Arminen (2014), Ozturk et al. (2016), Wang (2012), Yu-ming (2010), Neequaye and Oladi (2015), $\mathrm{Xu}$ and Lin (2015), Ahmed and Long (2012), Tao et al. (2008), Sarkodie and Strezov (2019), Al-Mulali et al. (2015a, 2015b), Dogan (2016), Liu et al. (2017a, 2017b), Bell et al. (2018), Brown et al. (2011), and Csereklyei et al. (2016) have applied similar variables in their energy and climate changes and come up with diverse findings.

Al-Mulali et al. (2015a, 2015b) applied ecological footprint as an indicator for environment to Investigate the environmental Kuznets curve (EKC) hypothesis for ninetythree countries, the group find EKC for the selected areas; Alola et al. (2019) studied the impact of trade policy, economic growth, fertility rate, renewable, and non-renewable energy consumption on ecological footprint in Europe, and they found non-renewable energy use contributing to the environment dilapidation and renewable energy sustaining the environment. Bagliani et al. (2008) applied ecological footprint as a measure to the environment in the analysis of sub-national area: the case of the Province of Siena (Italy), and they found a breakeven total ecological balance. Chen et al. (2006, October) researched on the effect of coal mining on China regional ecological footprint based on GIS, and they found coal mining detrimental to the ecological footprint of the coal mining area. Solarin and Bello (2018) utilized ecological footprint to researched on the persistence of policy shocks to an environmental degradation index for 128 developed and developing countries. They found evidence of non-reverting mean in the series for 96 countries. Wang et al. (2008) studied the effect of coal exploitation on groundwater and vegetation in the Yushenfu Coal Mine. They found that coal exploitation has adverse effect on ground water and vegetation.

Kivyiro and Arminen (2014) studied carbon dioxide emissions with energy consumption, economic growth, and foreign direct investment and found EKC for the six Sub-Saharan Africa. Ozturk et al. (2016) applied GMM approach to investigate the environmental Kuznets curve hypothesis for the upper middle and higher income. They found a negative relationship between ecological footprints and its determinants for the upper middle and higher income countries. They also found EKC for the same categories of countries. Wang (2012) applied EKC hypothesis in modeling the nonlinear relationship between $\mathrm{CO}_{2}$ emissions from oil and economic growth. The result fails to support EKC. Yu-ming (2010) researched Kuznets curve analysis of guangxi ecological footprint and energy consumption. They found inverted U-shaped curve for ecological footprint and energy consumption. Neequaye and Oladi (2015) investigate environment performance with growth, and FDI, and found existence of EKC for carbon emission and greenhouse emissions from the energy and industrial sectors. Xu and Lin (2015) investigate factors affecting carbon dioxide $\left(\mathrm{CO}_{2}\right)$ emissions in China's transport sector. They found EKC hypothesis existing for the case of economic growth and carbon emission. Ahmed and Long (2012) tested environmental Kuznets curve for Pakistan, and found a supporting result for the EKC hypothesis between economic growth and carbon emission. Tao et al. (2008) tested the environmental Kuznets curve in China. They found long-run cointegration relationship between per capita emission and economic growth. Sarkodie and Strezov (2019) employed a panel data to test the effect of foreign direct investments, economic development, and energy consumption on greenhouse gas emissions in developing countries. The result supports EKC for India and South Africa. Al-Mulali et al. (2015a, 2015b) tested for the environment Kuznets curve hypothesis, and found inverted U-shaped relationship between carbon emission and the selected series. Dogan (2016) applied ARDL to research the impact of agriculture and environmental Kuznets curves in the case of Turkey. They found EKC for the Turkey and negative relationship between agriculture and carbon emission. Liu et al. (2017a, 2017b) investigate the impact of renewable energy and agriculture on carbon dioxide emissions with environmental Kuznets curve in four selected ASEAN countries. The result did not support the EKC in the selected countries.

Bell et al. (2018) research on sustainable bioeconomy in EU and found that it contributes to climate change mitigation and advocate that some land built-ups foster negative carbon emissions. Brown et al. (2011) investigate the energy use implication to the economic growth and found a positive relationship between energy and economic growth. Csereklyei et al. (2016) researched on the relationship between energy and economic growth in a stylized fact, and they found a positive relationship between energy and economic growth. Ohlan (2016) researched on the implication of renewable and nonrenewable energy consumption and economic growth in India and found a positive effect of energy use on Indian economic growth.

\section{Theoretical review/background}

The theoretical background of this study is based on the environmental Kuznets curve (EKC) hypothesis. The supporters of Kuznets curve question the reliability of the linear and direct relationship between environment quality and economic growth (per capita income). Kuznets (1995) was the initiator of EKC hypothesis when he investigates the relationship between the per capita income and income inequality. He argued that the income inequality gap is reduced at a turning point where the rural farmers switched to white-collar jobs which give them access to higher per capita income. After the introduction of the Kuznets curve, 
many environmentalists and energy economists have started applying the hypothesis to test the environment quality with respect to historical pattern of economic growth. The first proponents of environmental Kuznets curve are Grimes and Kentor (2003), Shafik and Bandyopadhyay (1992), and Panayotou, (1993). The EKC hypothesis is adopted to monitor the performance of environment while the economy is growing. The proponents of EKC theory came up with the view of historical pattern of economic growth, and hence group the pattern into 3 effects: the scale effect, structural/ technical effects, and composite effect. This is demonstrated in Fig. 1.

\section{Materials and methods}

\section{Model specification, variables, and data}

The model specification is based on the theoretical background of this study, EKC, with different models that accommodate different selected variables for different purposes. The two basic models are the environment and economic growth models. The environment model presents the impact of the explanatory variables (GDP per capita, squared GDP per capita, industrialization, agriculture, fossil fuel energy mix, and coal energy use) on the dependent variable (ecological footprint), while the economic growth model presents the impact of the selected explanatory variables (industrialization, agriculture, and energy use) on the dependent variable (economic growth). Also, in attempt to have insight on the direct impact of coal as an energy source, the environment model is further split into two models, one with fossil fuel energy mix and the other with just coal as a single energy use. The model specification of ARDL bound testing for cointegration (for short run and long run) estimations and analysis is also based on Pesaran and Shin (1998) and Pesaran et al. (2001) modeling of the cointegration. Hence, the specifications are presented in the equations below as follows:

$E F P=\left(Y, Y,{ }^{2} I n d, E u, A G\right)$

$E F P=\left(Y, Y,{ }^{2}\right.$ Ind $\left., C O A L, A G\right)$

$Y=(I n d, E u, A G)$

From Eq. (1) to (3), EFP is ecological footprint as an environmental indicator or a measure of environmental dilapidation, $Y$ and $Y^{2}$ are GDP per capita and GDP per capita squared for measure of economic growth respectively, Ind is a measure of industrialization, $\mathrm{EU}$ is a measure of mix energy use/consumption, $\mathrm{AG}$ is agriculture, and COAL

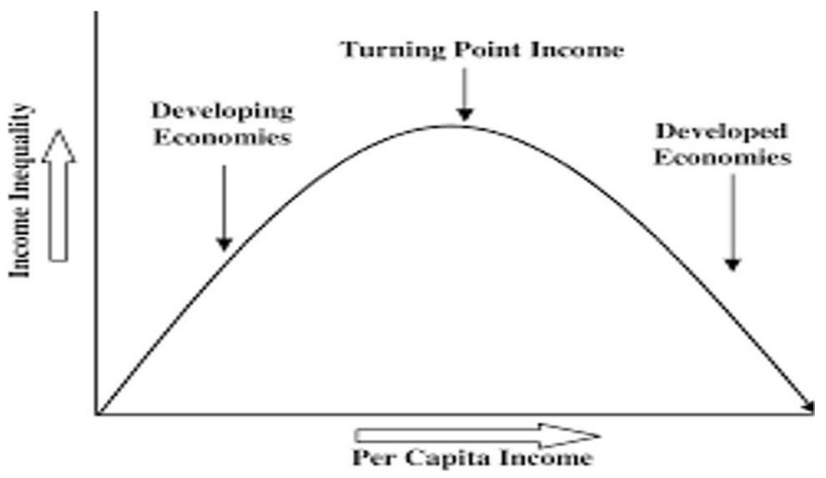

Fig. 1 Environmental Kuznets curve

represents the coal as a single energy use. The above equations are re-specified in an estimable econometrics and empirical forms as follows:

\section{Econometric form}

$E F P=a_{1}+a_{2} Y_{i t}+a_{3} Y_{i t}^{2}+a_{4} I_{i t}+a_{5} E U_{i t}+a_{6} A G_{i t}+\mu_{i t}$

$E F P=a_{1}+a_{2} Y_{i t}+a_{3} Y_{i t}^{2}+a_{4} I n d_{i t}+a_{5} C O A L_{i t}+a_{6} A G_{i t}+\mu_{i t}$

$Y=a_{1}+a_{2} \operatorname{Ind}_{i t}+a_{3} E U_{i t}+a_{4} A G_{i t}+\mu_{i t}$

\section{Empirical model}

$\ln E F P=a_{1}+a_{2} \ln Y_{i t}+a_{3} \ln Y_{i t}^{2}+a_{4} \ln \operatorname{Ind} d_{i t}$ $+a_{5} \ln E U_{i t}+a_{6} \ln A G_{i t}+\mu_{i t}$

$\ln E F P=a_{1}+a_{2} \ln Y_{i t}+a_{3} \ln Y_{i t}^{2}+a_{4} \ln \operatorname{In} d_{i t}$ $+a_{5} \ln C O A L_{i t}+a_{6} \ln A G_{i t}+\mu_{i t}$

$\ln Y=a_{1}+a_{2} \ln \operatorname{In} d_{i t}+a_{3} \ln E U_{i t}+a_{4} \ln A G_{i t}+\mu_{i t}$

All the variables have been defined as they first appeared in Eq. (1)-(3), the sample period which is $1974-2018$ is represented with $t . \mu_{i t}$ is the error term, and $a_{i}$ denotes the parameter or the coefficient to be estimates and analyzed, where $I=1,2,3,4,5$, and 6 . All variables are expressed in their natural logarithmic form. Ecological footprint (measured in gha per person) is used as a better option of indicator to measure or proxy to the environment. As noted earlier, that ecological has gained a maximum support for a good proxy to environment by different scholars (Bagliani et al. 2008; Wang et al. 2013; Al-Mulali et al. (2015a, 2015b; Ozturk et al. 2016; Uddin et al. 2017; Alola et al. 2019; Ulucak and lin, 2017; Solarin and Bello 2018; Katircioglu et al., 2018; Duman et al. 2020). Turkey's ecological 
footprint components can be grouped with percentage of each component as follows: cropland footprint with 53\%, carbon footprint with $17 \%$, grazing land footprint with $16 \%$, forest land footprint with $9 \%$, and fishing ground footprint and built-up land footprint with 4 and 1\%, respectively. This is presented in Fig. 2.

As displayed in Fig. 2, cropland footprint has the largest share in Turkey's ecological footprint followed by the carbon footprint emission. This portray a change in the Turkey's ecological footprint; hence, carbon footprint was reported to have the largest share from 1961 to 2014 (Global Footprint Network 2012).

Economic growth is measured as real GDP per capita (constant 2010 US\$) with squared real GDP per capita shown the turning point in EKC theory (Kivyiro and Arminen 2014). Industrialization is a measure of manufacturing or industry valued added (Opoku and Boachie 2020). AG is a measure of agriculture value added (constant 2010 US\$), and it comprises cropland and farming, forestry, and fishing (Liu et al. (2017a, 2017b). EU and COAL measure the energy use/consumption of Turkey, while EU comprises the basic energy sources (oil, natural gas, and coal) and COAL was used as a single energy source in a different model. The reason for this is the author's interest on the significant impact rate of coal in Turkey's environment following the coal expansion policy of the country. They are expressed in million tonnes oil equivalent. The summary and definitions of the variables and their measurements are shown in Table 2.

With the level of industrial progression in Turkey which is characterized by excessive energy (fossil fuel) use, it is expected that the parameter $\left(a_{4}\right)$ will be positively related to environment degradation as proxy with ecological footprint. In the same manner, the parameters $\left(a_{5}\right)$ of energy use and coal which are majorly dependent on fossil fuels are expected to have positive relation with environment degradation. The parameter $\left(a_{6}\right)$ of agriculture is hypothesized to be positive considering the major components of the ecological footprint are agriculture related and the activities (such as land reclamation, chemical utilization, herders activities) that are obtainable in the sector are capable of emitting greater percentage of pollution. Also, for the EKC to hold, the parameters $\left(a_{2}\right.$ and $\left.a_{3}\right)$ of GDP per capita and squared GDP per capita are expected to be positive and negative, respectively (Wang, 2012).

The data for this study spanned from 1974 to 2018 and were sourced from different sources ranging from Global Footprint Network 2019 for ecological footprint to British Petroleum (BP) Statistical Review of World Energy (2019) for energy use and coal, and World Development Indicator (WDI, 2019) for GDP per capita, industrialization, and agriculture. The selected period of this study was influenced by the availability of data for the selected variables. Turkey as a choice and focused of this study is based on the current industrial and economic expansion of the country coupled with the recent energy related policies of the authorities of Turkey.

\section{Empirical methodology, result, and discussion}

The empirical methods employed in this research are descriptive statistics, unit root testing, structural break test, optimal lag selection, cointegration test, and causality analysis.
Fig. 2 Turkey Ecological Footprint per person. Source: Prepared by author with Global Footprint Network 1961-2016 Data

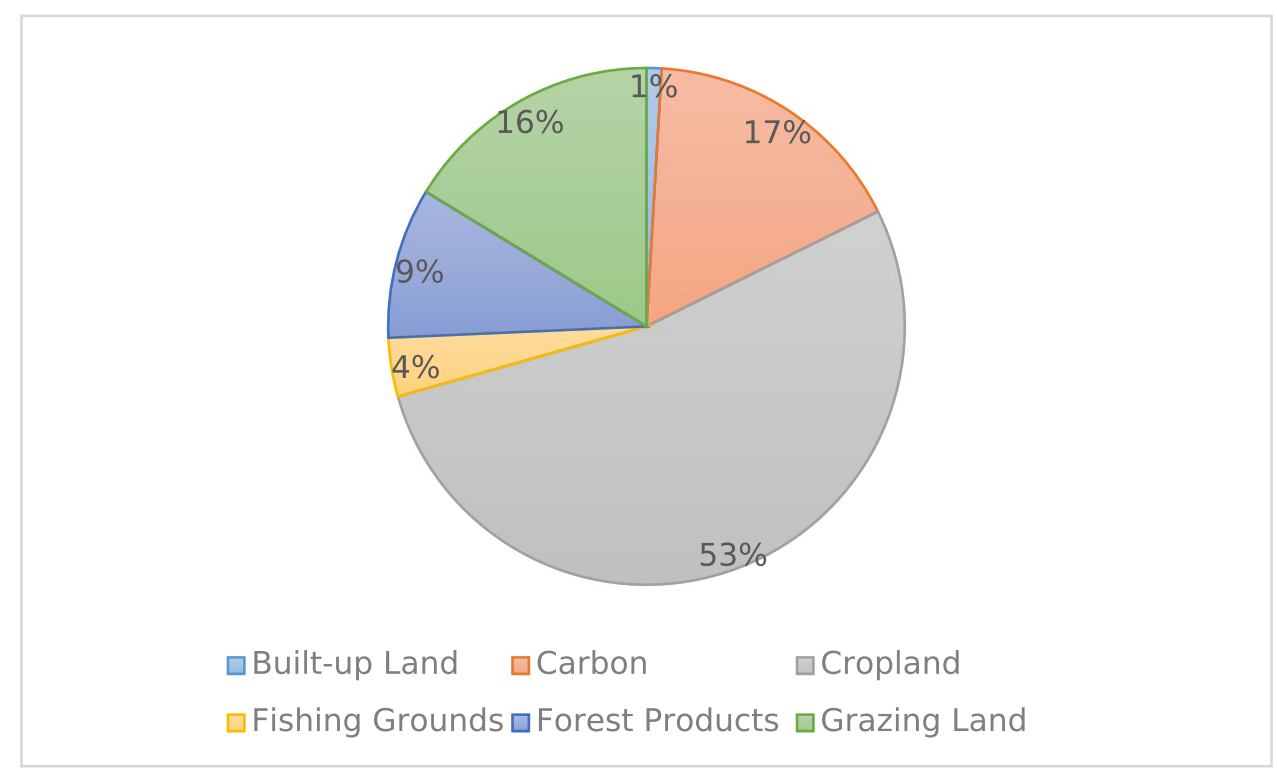


Table 2 Summary of variables

\begin{tabular}{|c|c|c|c|c|}
\hline Variables & Short forms & Measurements & Sources & Literature \\
\hline Ecological footprint & EFP & Constant per capita & Global Footprint Network (2018) & $\begin{array}{l}\text { Al-Mulali et al. (2015a); Ozturk et al. } \\
\text { (2016); Uddin et al. (2017); Ulucak } \\
\text { and lin (2017) }\end{array}$ \\
\hline GDP per capita & $\mathrm{Y}$ & Constant 2010 US\$ & Updated WDI (2019) & Kivyiro and Arminen (2014) \\
\hline GDP per capita squared & $\mathrm{Y}^{2}$ & Constant 2010 US\$ & Updated WDI (2019) & Kivyiro and Arminen (2014) \\
\hline Industrialization & Ind & Constant 2010 US\$ & Updated WDI (2019) & Opoku and Boachie (2020) \\
\hline Energy use & EU & Million tonnes oil equivalent & $\begin{array}{l}\text { British Petroleum (BP) Statisti- } \\
\text { cal Review of World Energy } \\
\text { (2019) }\end{array}$ & Shahbaz et al. (2017) \\
\hline COAL & COAL & Million tonnes oil equivalent & $\begin{array}{l}\text { British Petroleum (BP) Statisti- } \\
\text { cal Review of World Energy } \\
\text { (2019) }\end{array}$ & $\begin{array}{l}\text { Yu-ming (2010); Chen et al. (2006, } \\
\text { October); }\end{array}$ \\
\hline Agriculture & AG & Constant 2010 US\$ & Updated WDI (2019) & Liu et al. (2017a, 2017b) \\
\hline
\end{tabular}

Source: Author compilation

Descriptive statistics was used in this study to confirm the characteristics and the suitability of the data applied in this study. Among the features of the descriptive statistics are mean, median, minimum and maximum, skewness, kurtosis, and Jarque-bera. The size and the variability of the data and the variables are highlighted with the features such as mean, median, standard deviation, minimum, and maximum, while the stability, normality, and the conformity of the data to symmetric or asymmetric is tested with skewness, kurtosis, and Jarque-bera. On the size of the data and the variables, with consideration on the minimum and maximum, GDP per capita is the highest among the variables followed by energy use and coal. Also, based on mean variable with the highest variability is GDP per capita followed by energy use and coal. The normality of the data is accessed and determined with the probability (significance) of Jarque-bera in the variables, while ecological footprint, GDP per capita, agriculture, coal, and energy use are normally distributed, the hypothesis of normally distributed is rejected in some variable (Industry). Considering the level of normality of the data and the variables which is relatively higher than the variable that is not normal, author considers linear scientific approach the best method for estimates and analyses of this study.

\section{Unit root/stationarity}

Unit root/stationarity is adopted in this study to test the stationarity and the order $(\mathrm{I}(0), \mathrm{I}(1)$, or mixed order) of integration. Time series data are known with instability that beclouds the scientific assessment of the data with respect to study. It is essential to test the stationarity of time series in any country-specific analysis to make sure the approach, analysis, and findings are obtained. The current study employed both the conventional (Philip-Perron (Perron 1990), augmented Dickey-Fuller (ADF 1979), and Kwiatkowski-Philips-Schmidt-Shin (Kwiatkowski et al. 1992) approaches of ascertaining the unit root and Dickey-Fulller structural break as a robust check to the findings of the conventional methods. Most times, conventional approaches are weak in the face of structural break that might have impacted heavily on the movement of the variables selected to study an economy. Such structural break always leaves a permanent impact (shock) or break in the economy. Example of such structural break is the present COVID 19 pandemic that have left remarkable impact on the global economy. From the conventional approach, the author found the data non-stationary at level and most of the variables in the data are integrated at I(1) except ecological footprint. In summary, unit root and mixed order of integration was uncovered. Going further to test reliability of the findings from the conventional method of unit root testing, Dickey-Fuller structural break method was employed for robust checking. Structural break established that the variables have unit root in the face of structural changes in the following year 1979 for ecological footprint, 2005 for energy consumption, 2007 for GDP per capita, 2000 for industrialization, 2000 for Agriculture, and 2000 for coal consumption. From the accounted dates, the structural changes that affected the selected variables spanned from 1979 to 2007, of which majority of the shocks or changes occurred during the period of 2000 as it appeared in majority of the variables (industrialization, agriculture, and coal consumption). The periods of the shocks were all well accommodated in the period of this study, 1974-2018. Within these periods, two notable structural changes (energy shock and monetary policy) occurred that are capable of leaving a permanent shock to the economies of many nations including Turkey and 
impact the stability of their data and variables in research study. Specifically, oil crises that took place in 1979 through 2000s exemplified the structural shock from the angle of energy crisis. The shocks came as a result of fluctuations in the oil prices caused by the level of production and supply of oil due to some political instability and macroeconomic policies of the involved economies. Among the pioneers of the energy shocks was the 1979 oil crisis caused by Iranian Revolution of 1979. The global oil supply decreased because of the shutdown of production due to revolution and this pushed up the price of the product and this created a global shock. Even the 1980 Iraq-Iran war affected the oil production capacity of the region which caused another global energy crisis. Also, the 1990 Iraq's inversion of a fellow OPEC member, Kuwait, caused another energy crisis that was short lived before the 2000s energy crisis (Hamilton and Keim 2009; Roubini and Setser 2004). Moreover, the worries of energy crisis that took place in 2000s are majorly caused by the Middle East tension, excessive demand of oil by China and the fall of value on US dollar. There was an upward trend of rise in oil price especially, from 2003 to 2008. Another notable structural change was introduced by the monetary policy of US which affected its domestic economy with that of the foreign countries that pegged their exchange rate to US currency. USA in a bid to enhance and boost its export and investment policies devalued its currency, and this affected the economy of other countries including Turkey who pegged their currencies to US currency. As the US export and investments are increasing, the export and investment of the foreign countries that pegged their currencies to US currency are decreasing because their currencies appreciate thereby making the prices of their products increases because of their currency appreciation. Turkey was among the victims of this monetary policy of USA and the structural changes which are capable of impacting the stationarity of the variables involved. Turkey's experience of sever financial crises in 2001 and the 2008/9 global financial meltdown contributed to the Turkey's structural change capable of interfering with the stability of its economic indicators. The output of both conventional unit root test and the structural shock are presented in Tables 3 and 4.

\section{Test for cointegration (both the short and long run) and diagnostic tests}

This study applied bound (ARDL) testing approach to test for the cointegration of the model. That is if the variables are conitegrated, and whether there exists long run relationship among the variables. Both the long-run and short-run (error correction) relationships were determined with bound testing. To test for the cointegration, it is hypothesized that there is no cointegration or long-run relationship between the variables with null hypothesis as $H_{0}=$ long run coefficients (e.g., $a_{1}=a_{6}=0, F-$ stat $<$ bounds), and there is cointegration or long-run relationship between the variables with alternative hypothesis as $H_{1}=$ long-run coefficients (e.g. $a_{1}=a_{6} \neq 0, F-$ stat $>$ bounds). In sum, when the $F$-stats is greater than bound values (upper bounds $\mathrm{I}(0)$ ) and lower bounds (I(1)), the null hypothesis is rejected and vice versa. The approach (bound testing) applied in the current study has some striking advantages over the other methods (Engle and Granger 1987; Johansen 1988 and Johansen and Juselius, 1990) in determining the cointegration and long-run relationship between the variables. Among the disadvantages of both Engle and Granger (1987) and Johansen (1988) are the biasness of small sample from exclusion of short run dynamics (Alam and Quazi 2003) and the rigidity method of the acceptable order of integration (I(1)), respectively. The autoregressive distribution lag (ARDL) and bound testing approach initiated by Pesaran et al. (2001) has the ability to test the cointegration and the long-run relationship between the variables in a mixed order $(\mathrm{I}(0), \mathrm{I}(1)$ or mixed order). Also, the bound approach has the ability to test the cointegration even when the

Table 3 Summary of statistics

\begin{tabular}{lllllll}
\hline Variable & LEFP & LGDPPC & LINDUS & LAGRIC & LCOAL_ & LENERGY \\
\hline Mean & 2.645040 & 7969.491 & $1.17 \mathrm{E}+11$ & $5.44 \mathrm{E}+10$ & 18.82227 & 57.68679 \\
Median & 2.644677 & 7343.321 & $9.51 \mathrm{E}+10$ & $5.09 \mathrm{E}+10$ & 17.13300 & 51.98004 \\
Maximum & 3.392690 & $14,062.73$ & $3.03 \mathrm{E}+11$ & $8.29 \mathrm{E}+10$ & 38.45745 & 124.1634 \\
Minimum & 1.927702 & 4744.443 & $3.43 \mathrm{E}+10$ & $3.90 \mathrm{E}+10$ & 5.694000 & 17.11888 \\
Std. Dev & 0.446448 & 2660.151 & $7.59 \mathrm{E}+10$ & $1.16 \mathrm{E}+10$ & 9.741478 & 31.49406 \\
Skewness & 0.219819 & 0.792812 & 0.964591 & 0.892942 & 0.402741 & 0.516486 \\
Kurtosis & 1.734018 & 2.603130 & 2.920598 & 2.838702 & 2.106593 & 2.088538 \\
Jarque-Bera & 3.217821 & 4.786808 & 6.679421 & 5.760919 & 2.592502 & 3.400214 \\
Probability & 0.200106 & 0.091318 & 0.035447 & 0.056109 & 0.273555 & 0.182664 \\
Sum & 113.7367 & $342,688.1$ & $5.05 \mathrm{E}+12$ & $2.34 \mathrm{E}+12$ & 809.3574 & 2480.532 \\
Sum Sq. Dev & 8.371266 & $2.97 \mathrm{E}+08$ & $2.42 \mathrm{E}+23$ & $5.66 \mathrm{E}+21$ & 3985.648 & $41,658.78$ \\
Observations & 43 & 43 & 43 & 43 & 43 & 43 \\
\hline
\end{tabular}

Source: Computed by the author 
Table 4 Stationarity test

\begin{tabular}{|c|c|c|c|c|c|}
\hline \multicolumn{2}{|l|}{ Variables } & \multicolumn{2}{|l|}{ At Level } & \multicolumn{2}{|l|}{ 1st Diff } \\
\hline & With intercept & Intercept and trend & $\begin{array}{l}\text { With intercept } \\
P P\end{array}$ & Intercept and trend & Decision \\
\hline LEFP & -1.0313 & $-5.0577 * *$ & $-12.5647 * * *$ & $-12.5154 * * *$ & MIXED \\
\hline LGDP & 3.3174 & -0.4284 & $-5.6514 * * *$ & $-6.6709 * * *$ & $\mathrm{I}(1)$ \\
\hline LEU & 4.7674 & 0.7248 & $-6.1549 * * *$ & $-8.6953 * * *$ & $\mathrm{I}(1)$ \\
\hline LIND & 5.4141 & 0.6351 & $-4.7499 * * *$ & $-5.7347 * * *$ & $\mathrm{I}(1)$ \\
\hline LAGR & 3.1771 & -0.7465 & $-10.7282 * * *$ & $-14.4175 * * *$ & $\mathrm{I}(1)$ \\
\hline LCOAL & 1.9470 & -2.2467 & & & \\
\hline & & & $A D F$ & & \\
\hline LEFP & -0.5784 & $-4.9574 * *$ & $-10.7182 * * *$ & $-10.5901 * * *$ & MIXED \\
\hline LGDP & 2.2112 & 0.4869 & $-5.6288^{* * *}$ & $-6.4166^{* * *}$ & $\mathrm{I}(1)$ \\
\hline LEU & 2.3161 & -1.0320 & $-6.1529 * * *$ & $-7.2360 * * *$ & $\mathrm{I}(1)$ \\
\hline LIND & 3.0763 & -0.0292 & $-4.7499 * * *$ & $-5.6953 * * *$ & $\mathrm{I}(1)$ \\
\hline LAGR & 2.6780 & 0.2735 & $-10.7282 * * *$ & $-11.8826^{* * *}$ & $\mathrm{I}(1)$ \\
\hline LCOAL & 1.3186 & -2.2467 & $\begin{array}{l}-8.9515^{* * * *} \\
K P S S\end{array}$ & $-9.2881 * * *$ & $\mathrm{I}(1)$ \\
\hline LEFP & $0.7955^{* * *}$ & 0.0918 & 0.0538 & 0.0540 & \\
\hline LGDP & $0.8110 * * *$ & $0.2044 * *$ & $0.5111 * *$ & 0.0888 & \\
\hline LEU & $0.8389 * * *$ & $0.2170 * *$ & $0.6375^{* *}$ & $0.1273 *$ & \\
\hline LIND & $0.7937 * *$ & $0.2085^{* *}$ & $0.6438 * *$ & $0.1332 *$ & \\
\hline LAGR & $0.8041 * * *$ & $0.2040 * *$ & $0.3625^{*}$ & $0.1778 * *$ & \\
\hline LCOAL & $0.8364 * * *$ & $0.1780 * *$ & 0.2773 & 0.0902 & \\
\hline
\end{tabular}

a: $(*)$ Significant at the $10 \% ;(* *)$ significant at the $5 \% ;(* * *)$ significant at the $1 \%$. (b): $p$-value according to (1) Maclean et al. (1996) one-sided $p$-values and (2) Kwiatkowski et al. (1992). Source: Computed by the author

explanatory variables are endogenous and equally suitable for smaller samples. Following the Pesaran and Shin (1998) and Pesaran et al. (2001), the model specifications for the long run and the short run (Error correction model) are as follows:

$$
\begin{aligned}
\ln E F P_{t}= & \varnothing+a_{1} \ln E F P_{t-1}+a_{2} \ln Y_{t-1}+a_{3} \ln Y^{2}{ }_{t-1}+a_{4} \ln I n d_{t-1}+a_{5} \ln E U_{t-1}+a_{6} \ln A G_{t-1} \\
& +\sum_{i=0}^{\rho-1} \delta_{1} \Delta \ln E F P_{t-i}+\sum_{i=0}^{q-1} \delta_{2} \Delta \ln Y_{t-i}+\sum_{i=0}^{q-1} \delta_{3} \Delta \ln Y_{t-i}^{2} \\
& +\sum_{i=0}^{q-1} \delta_{4} \Delta \ln I n d_{t-i}+\sum_{i=0}^{q-1} \delta_{5} \Delta \ln E U_{t-i}+\sum_{i=0}^{q-1} \delta_{6} \Delta \ln A G_{t-i}+E C M_{t-i}+\mu_{t}
\end{aligned}
$$

$$
\begin{aligned}
\ln E F P_{t}= & \varnothing+a_{1} \ln E F P_{t-1}+a_{2} \ln Y_{t-1}+a_{3} \ln Y^{2}{ }_{t-1}+a_{4} \ln I n d_{t-1}+a_{5} \ln C O A L_{t-1} \\
& +a_{6} \ln A G_{t-1}+\sum_{i=0}^{\rho-1} \delta_{1} \Delta \ln E F P_{t-i}+\sum_{i=0}^{q-1} \delta_{2} \Delta \ln Y_{t-i}+\sum_{i=0}^{q-1} \delta_{3} \Delta \ln Y_{t-i}^{2} \\
& +\sum_{i=0}^{q-1} \delta_{4} \Delta \ln \operatorname{In} d_{t-i}+\sum_{i=0}^{q-1} \delta_{5} \Delta \ln C O A L_{t-i}+\sum_{i=0}^{q-1} \delta_{6} \Delta \ln A G_{t-i}+E C M_{t-i}+\mu_{t}
\end{aligned}
$$

$\ln Y_{t}=\varnothing+a_{1} \ln I n d_{t-1}+a_{2} \ln E U_{t-1}+a_{3} \ln A G_{t-1}$

$$
\begin{aligned}
& +\sum_{i=0}^{\rho-1} \delta_{1} \Delta \ln Y_{t-i}+\sum_{i=0}^{q-1} \delta_{2} \Delta \ln I n d_{t-i} \\
& +\sum_{i=0}^{q-1} \delta_{3} \Delta \ln E U_{t-i}+\sum_{i=0}^{q-1} \delta_{4} \Delta \ln A G_{t-i}+E C M_{t-i}+\mu_{t}
\end{aligned}
$$

The variables in Eqs. (10)-(12) have been defined in the previous equations above. The signs $\Delta, a_{1}, \delta_{1}, E C M_{t-i}$, and $\mu_{t}$ are the notation of first difference $(\Delta)$ of the selected variables which identifies the short-run relationship between the variables, long-run parameters or coefficient $\left(a_{1} \rightarrow a_{6}\right)$ of the variables, short-run parameters or coefficient $\left(\delta_{1} \rightarrow \delta_{6}\right)$ of the variables, the error correction model $\left(E C M_{t-i}\right)$ which shows the speed of convergence or adjustment to the equilibrium level in times of structural changes in the economy, and white noise error term $\left(\mu_{t}\right)$ (Table 5).

Table 6 displays the outcome of the cointegration (both the short and long run) relationships that exist between the selected variables in the above specified models. The output of the following tests: goodness of fit, autocorrelation/ serial correlation, bound testing of cointegration, heteroscedasticity, and CUSUM ${ }^{2}$ from all the tables, are explained together as follows: The goodness of fit for the three (3) models are represented with $R^{2}(0.992650 ; 0.991 ; 0.9987)$ and adjusted $R^{2}(0.987537 ; 0.986 ; 0.9985)$, respectively. The outputs show the part of dependent variables for the three (3) models that are explained by the explanatory variables, while the remaining are explained by the residuals. Durbin Watson tests for the three (3) models confirmed the 
Table 5 Structural break test

\begin{tabular}{lllllll}
\hline Variable & ADF & P-value & Lag & Breakdate & $C V(1 \%)$ & $C V(5 \%)$ \\
\hline & & & Level & & & \\
LEFP & -5.861787 & $<0.01 * * *$ & 9 & 1979 & -5.3476 & -4.8598 \\
LGDP & -4.003455 & 0.5188 & 9 & 2007 & -5.7191 & -5.1757 \\
LEU & -2.3766 & 0.99 & 9 & 2005 & -5.3476 & -4.8598 \\
LIND & -4.477960 & 0.2469 & 9 & 2000 & -5.719 & -5.176 \\
LAG & -6.623704 & $<0.0 * * *$ & 9 & 2000 & -5.719 & -5.176 \\
LCOAL & -5.310380 & $<0.035$ & 9 & 2000 & -5.719 & -5.176 \\
& & & 1 st diff & & & \\
LEFP & -10.71129 & $<0.01 * * *$ & 9 & 1993 & -5.3476 & -4.8598 \\
LGDP & -7.590529 & $<0.01 * * *$ & 9 & 2009 & -5.7191 & -5.1757 \\
LEU & -7.81889 & $<0.01 * * *$ & 9 & 2007 & -5.3476 & -4.8598 \\
LIND & -7.56522 & $<0.01 * * *$ & 9 & 2009 & -5.719 & -5.176 \\
LAG & -13.12988 & $<0.01 * * *$ & 9 & 2007 & -5.719 & -5.176 \\
LCOAL & -10.47145 & $<0.01 * * *$ & 9 & 2012 & -5.719 & -5.176 \\
\hline
\end{tabular}

a: $(*)$ Significant at the $10 \%$; (**) significant at the $5 \%$; (***) significant at the $1 \%$. Source: Author computation

absence of autocorrelation and serial correlation, and they are shown as from the tables as $(1.786571 ; 1.9585 ; 1.94)$; LM serial correlation test rejects the null hypothesis of the presence of serial correlation in all the models with insignificant results of both Chi-square and $p$-values. The bound testing of cointegration for the three (3) models confirmed the variables cointegrated at $1 \%$ significant level as displayed in the Table 6. Optimal lags for the three (3) models were determined with Akaike Information Criterion (AIC), and 3 was considered the appropriate lag. Error correction model (ECM) for the three (3) models were tested to confirm the speed of adjustments, and the outcomes show negative coefficients $(-0.11273 ;-0.3045 ;-0.568)$ and highly significant at $1 \%$ level each. This shows the ability of the dynamic model to return back to equilibrium level after a certain level of disequilibrium at the speed level of $0.1 \%$, 0.3 , and 0.6 , respectively. The existence of negative coefficient with high significant level also confirmed the existence of long-run relationship between the variables. The reliability and stability of the models were confirmed with CUSUM and CUSUM2 outputs as pictured in Figs. 3, 4, 5, 6, 7, and 8. According to model 1 from Table 6, the shortrun and long-run effects of the explanatory variables (per capita GDP, per capita GDP ${ }^{2}$, Industrialization, energy use, and agriculture) on environmental performance (ecological footprint) as represented in the first model are presented and interpreted as follows: a short-run and long-run (elasticity) positive relationship at $1 \%$ significant level is established between environment performance (ecological footprint) and economic growth (per capita GDP). The scale of the effect as shown by the values of the short run and long run coefficients $(0.001001)$ is relatively small. This translate to numerical expression as a $1 \%$ increase in economic growth will lead to $0.001001 \%$ increase in ecological footprint in both short and long run, respectively. This means that as the expansion of the economic performance/growth will translate to a relatively small level of dilapidated environment of Turkey. This is in line with the author's expectation. A shortand long-run negative (elasticity) relationship is established at quadratic point between environment (ecological footprint) and economic growth (per capita $\mathrm{GDP}^{2}$ ) at $1 \%$ significant level. This translates to positive effect of economic performance on environment performance at a turning point. It means that as the economy is growing at this level, there is less of environment dilapidation amounting to improvement in the quality of Turkey's environment. Quantitatively, a $1 \%$ increase in economic growth (per capita GDP2) will lead to $-0.00579 \%$ decrease on ecological footprint (less environment dilapidation) in both short and long run, respectively. This is a good trend for the Turkey's sustainable development and hence, a confirmation of inverted U-shape of environmental Kuznets curve (EKC) for Turkey. This supports the assertion of Wang 2012 and findings of Narayan and Narayan (2010), Neequaye and Oladi (2015), Xu and Lin (2015), Ahmed and Long (2012), and Song et al. (2008). A positive (elasticity) relationship is found between industrialization and environment (ecological footprint) in both short run and long run at 5 and $1 \%$, respectively. This is a pointer that the Turkey's experience of industrial expansion does not go without environmental implication. The environmental implication of Turkey's industrialization is negative which validates author's expectation. This shows that Turkey is still practicing and running a carbon filled economy and yet to adopt green economy. It is a sign that most manufacturing and industrial activities in Turkey are energy intensive which is anchored on fossil fuels (oil, natural gas and coal) energy 


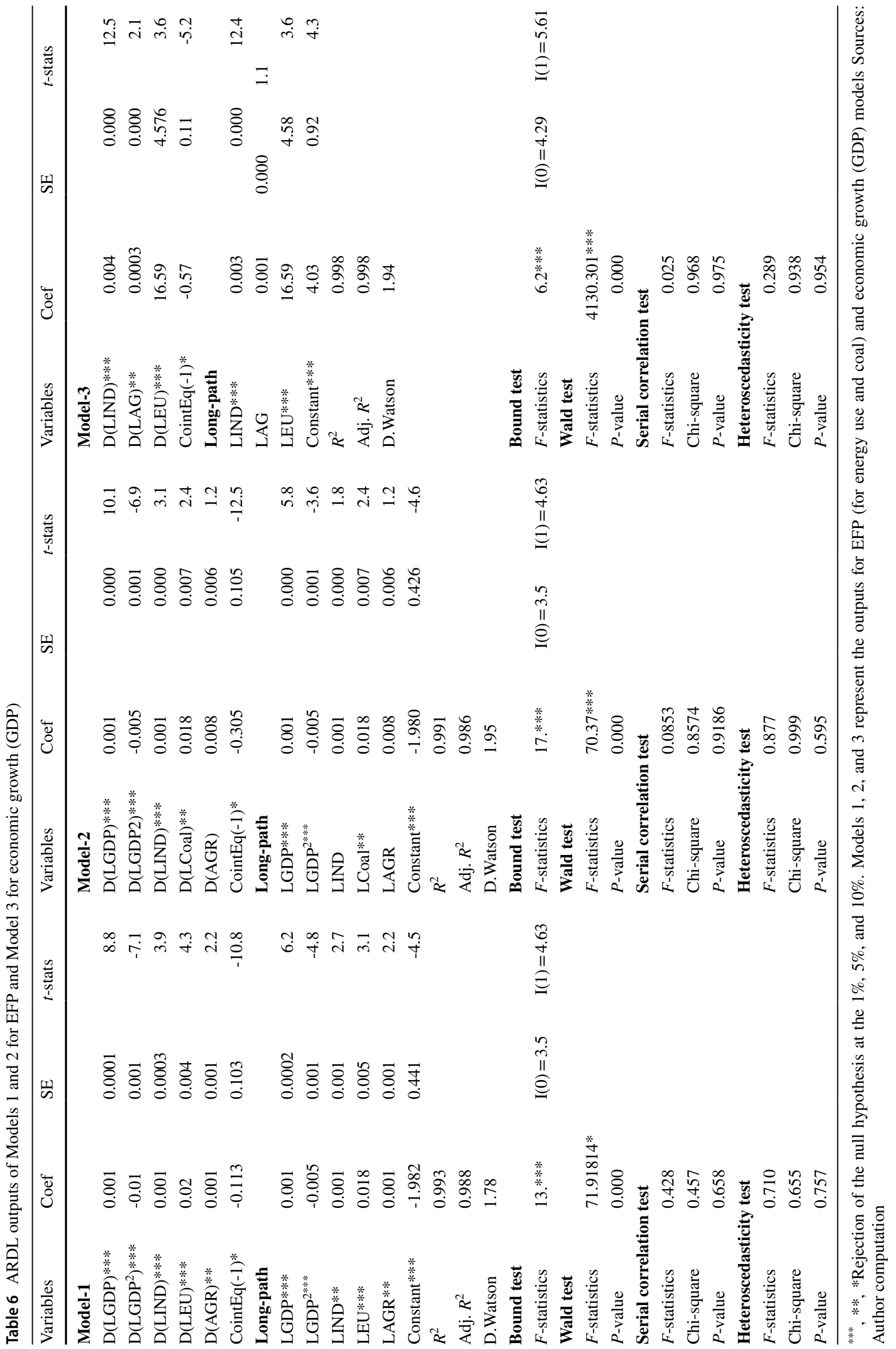




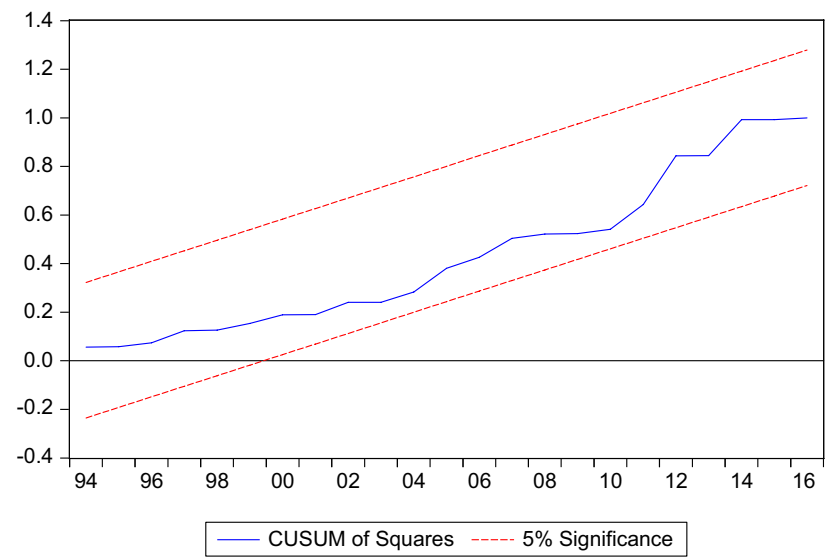

Fig. 3 CUSUM residual graphical plot for model 1 in Table 6 Source: Authors computation

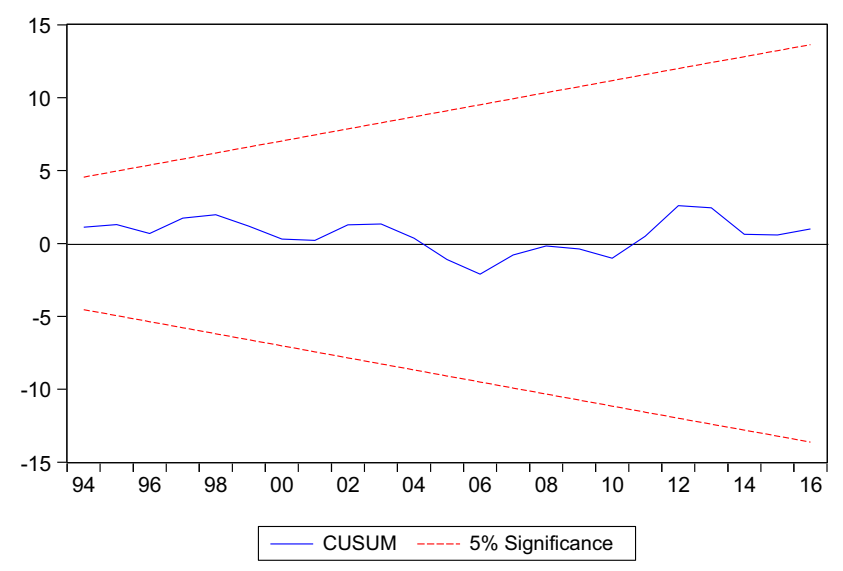

Fig. 4 CUSUM $^{2}$ residual graphical plot for model 1 in Table 6 Source: Authors computation

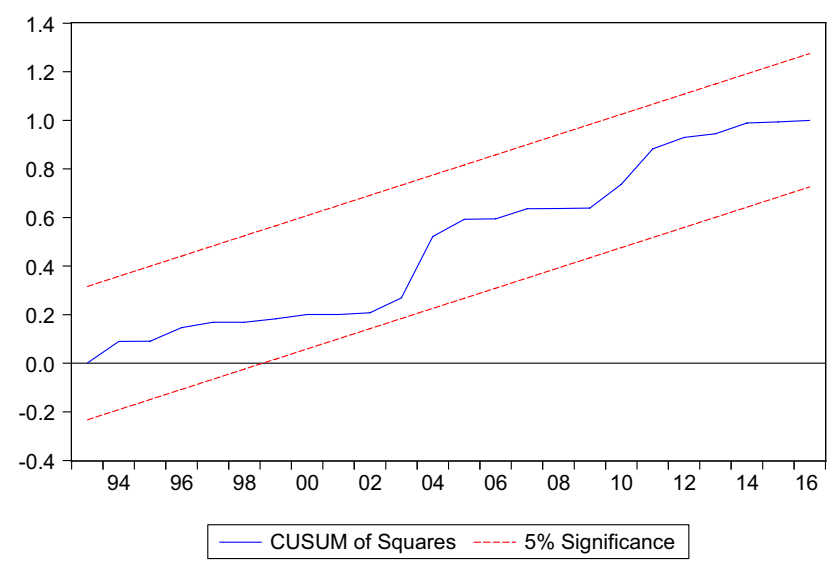

Fig. 5 CUSUM residual graphical plot for model 2 in Table 6 Source: Authors computation sources. Numerically, this translates to a $1 \%$ increase in industrialization amounts to $0.00133 \%$ increase in environmental dilapidation in both short and long run. This supports the findings of Liu et al. (2017b), Shahbaz et al. (2017), Hossain (2011), and Cherniwchan (2012). Also, a positive relationship established between energy use and environment (ecological footprint) in both short run and long run at $1 \%$, respectively. This is not surprising when consider the energy mix of the energy source of Turkey which are mostly fossil fuels. Excessive utilization of nonrenewable energy sources impacts the environment via air pollution. Energy utilization cuts across all the facets of Turkey's sector ranging from transportation to industry and agriculture. This equally validates the author's expectation of the existence of positive relationship between energy use and Turkey's environment. Hence, a $1 \%$ increase in energy use will lead to $0.018030 \%$ increase in ecological footprint (environment dilapidation) in both short and long run. This supports the findings of Sarkodie and Strezov (2019) for developing nations, Ozturk et al. (2016) for the case of 144 countries, and Al-Mulali et al. (2015a, 2015b). A positive (elasticity) relationship is initiated between agriculture and the environment (ecological footprint) in both short run and long run at 5\% significant level. This means that as the agricultural activities are inducing environment quality negatively. This backs the revelation on the Fig. 2 where the component parts of agricultural activities dominate the greater portion of the Turkey's ecological footprint. This translates to a $1 \%$ increase in agriculture will lead to $0.00118 \%$ increase in ecological footprint (dilapidated environment) in both short run and long run. This validates the author's expectation and supports the findings of Dogan (2016) for Turkish, Liu et al. (2017a, 2017b) for ASEAN for Pakistan.

From the model 2, the similar findings were established except in some cases especially on the part of COAL as the energy source. Hence, the models as expressed in Table 6 are same except the switch of the two-energy source (i.e., the complete energy source and coal). The short-run and long-run effects of the explanatory variables (per capita GDP, per capita GDP ${ }^{2}$, industrialization, COAL, and agriculture) on Turkey's environment performance (ecological footprint) as represented in the second model are presented and interpreted as follows: With the exception of per capita GDP ${ }^{2}$, positive relationships were found between ecological footprint and all the selected explanatory variables (per capita GDP, Industrialization, COAL, and agriculture). Hence, a positive (elasticity) relationship is found between economic growth (per capita GDP) and the environment (ecological footprint) in both short and long run, respectively, at $1 \%$ significant level. The scale of the effect as shown by the values of the short-run and long-run coefficients $(0.00103)$ is relatively small. This is numerical 
expressed as a $1 \%$ increase in economic growth will lead to $0.00103 \%$ increase in ecological footprint in both short and long run, respectively. This means that the expansion of the economic performance/growth will translate to a relatively small level of damaged environment of Turkey. This is in line with the author's expectation. A short- and long-run negative (elasticity) relationship is established at quadratic point between environment (ecological footprint) and economic growth (per capita GDP ${ }^{2}$ ) at $1 \%$ significant level. This translates to positive effect of economic performance on environment performance at a turning point. It means that as the economy is growing at this level, there is less of environment damage amounting to improvement in the quality of Turkey's environment. Quantitatively, a 1\% increase in economic growth (per capita GDP ${ }^{2}$ ) will lead to $-0.00523 \%$ decrease on ecological footprint (less environment dilapidation) in both short and long run, respectively. This is a good trend for the Turkey's sustainable development and hence, a confirmation of inverted U-shape of environmental Kuznets curve (EKC) for Turkey. This supports the assertion of Wang 2012 and findings of Narayan and Narayan (2010), Neequaye and Oladi (2015), Xu and Lin (2015), Ahmed and Long (2012), and Song et al. (2008). A positive (elasticity) relationship is found between industrialization and environment (ecological footprint) in both short run and long run at 1 and 10\% significant levels, respectively. This is a pointer that the Turkey's experience of industrial expansion does not go without environment implication. The environment implication of Turkey's industrialization is negative which validates author's expectation of positive sign in relationship between ecological footprint and industrialization. This shows that Turkey is still practicing and running a high carbon economy. It is a sign that most manufacturing and industrial activities in Turkey are energy intensive which is embedded on fossil fuels (oil, natural gas, and coal). Numerically, a $1 \%$ increase in industrialization amounts to 0.0010 and $0.00104 \%$ increase in environment dilapidation in both short and long run, respectively. This supports the findings of Liu et al. (2017b), Shahbaz et al. (2017), Hossain (2011), and Cherniwchan (2012). Also, a positive relationship established between COAL and environment (ecological footprint) in both short run and long run at $1 \%$, respectively. This is not surprising when consider the amount of emission from coal as the energy source in Turkey. This equally validates the author's expectation of the existence of positive relationship between COAL and Turkey's environment. Hence, a $1 \%$ increase in COAL will lead to $0.0177 \%$ increase in ecological footprint (environment dilapidation) in both short and long run. This supports the findings of Yu-ming (2010), Chen et al. (2006, October), and Wang et al. (2008). A positive (elasticity) relationship is initiated between agriculture and the environment (ecological footprint) in both short run and long run. This means that the agricultural activities are inducing environment quality negatively. This backs the revelation on the Fig. 2 where the component parts of agricultural activities dominate the greater portion of the Turkey's ecological footprint. This translates to a $1 \%$ increase in agriculture will lead to $0.0075 \%$ increase in ecological footprint (dilapidated environment) in both short run and long run. This validates the author's expectation and supports the findings of Dogan (2016) for Turkish, Liu et al. (2017a, 2017b) for ASEAN for Pakistan.

Model 3 presents the result of economic growth model. The short-run and long-run effects of the explanatory variables (industrialization, energy use, and agriculture) on Turkey's economic performance (per capita GDP) as represented in the third model are presented and interpreted as follows: A positive (elasticity) relationship is found between economic growth and industrialization in both short run and long run at $1 \%$ significant level. This shows that industrialization has a positive impact on Turkey's economic growth. Hence, numerically, a $1 \%$ increase in industrialization will lead to $0.0035 \%$ increase in economic growth (per capita GDP) in both short and long run, respectively. This validate author's expectation and support the findings of Ossadzifo (2018), Opoku and Yan (2019). This is expected from Turkey's economy because of the strategic position of the country and according to the sectorial structure of the economy, manufacturing sector which is factored in industrialization is among the highest contributor to the economic growth of Turkey (see Table 1). A positive (elasticity) relationship is established between economic growth (per capita GDP) and agriculture in both short run and long run, respectively. Quantitatively, a one percentage increase in agriculture increases the economic growth (per capita GDP) $0.0035 \%$ at $5 \%$ significant level. This is equally expected because Turkey is known with its global impact via farming and agricultural products. This supports the findings of Awokuse (2009), Raza et al. (2019), Tsakok and Gardner (2007), and Kaya et al. (2012). Also, a positive (elasticity) and significant relationship is initiated between energy use and economic growth in both short run and long run. Virtually, all the sectors of Turkish economy are energy intensive, which translate into energy impacting the economy both directly and indirectly. This is shown with the scale of its (energy use) effect on economic growth; hence, a $1 \%$ increase in energy use will lead to $16.5929 \%$ increase in economic growth (per capita GDP). This is not surprising considering the level of energy utilization in Turkish economic performance. This finding supports the findings of Csereklyei et al. (2016), Ohlan (2016), Brown et al. (2011), and Siddiqui (2004). 


\section{Granger causality analysis (VECM)}

The current study employed Granger causality approach as a robust check to the findings of the cointegration estimation. The conventional linear and non-linear approaches such as ARDL rely on the signs and relationships that exist between the dependent and independent variable to make their judgments on the analyses. This is always the problem of linear analysis without much insight on the power of forecasting the movement of the series, and no insight on the causality effect or relationships that exist between the series. It is important to stretch the signs and relationships found among the series via linear approach by establishing a forecasting or predicting relationships among the series for proper policy advice, and the Granger causality is the valuable tool for this. It helps to build a historical trend among the series by determining if one series is useful in predicting another series. Because of the mixed order of integration that existed among the series, vector error correction model (VECM) is considered the best Granger causality approach to utilize for effective and insightful analysis void of erroneous conclusion. Therefore, the empirical estimates of both the short-run and long-run (Block exogenous/VECM) Granger causality are presented in Table 7.

The results displayed in the table above shows a unidirectional causal relationship between the following series in the short run: ecological footprint and industrialization (industrialization Granger causing ecological footprint), between economic growth and industrialization (transmitting from industrialization to economic growth), energy use and agriculture, and between energy use and coal. Bidirectional causal relationship was initiated between agriculture and economic growth (two-way transmission between agriculture and economic growth), between industrialization and agriculture. In the long run, the causal relationship was established as follows: a unidirectional causal relationship between ecological footprint and energy use (transmitting from energy use to ecological footprint), ecological footprint, economic growth and industrialization (transmitting from ecological footprint and industrialization to economic growth),industrialization, ecological footprint and energy use (transmitting from ecological footprint and energy use to industrialization) economic use and agriculture (transmitting from agriculture to energy use), agriculture, economic growth and industrialization (transmitting from economic growth and industrialization to agriculture), and coal and agriculture (transmitting from agriculture to coal).

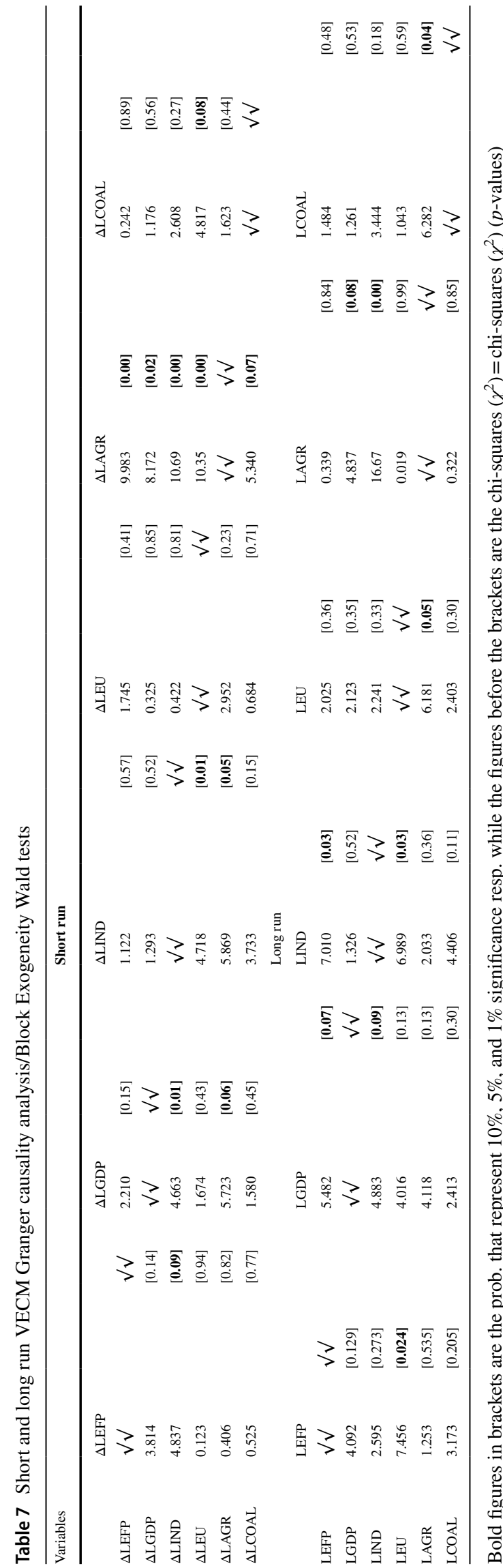




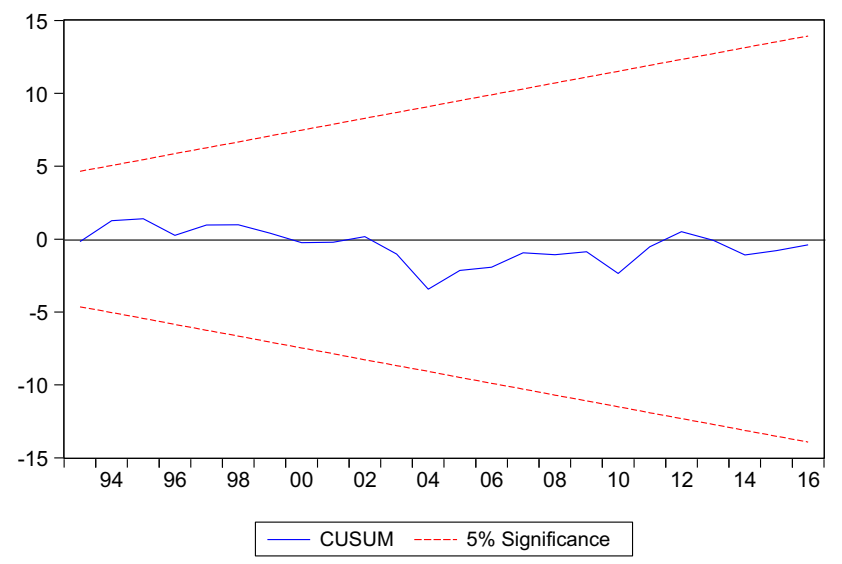

Fig. 6 CUSUM $^{2}$ residual graphical plot for model 1 in Table 6 Source: Authors computation

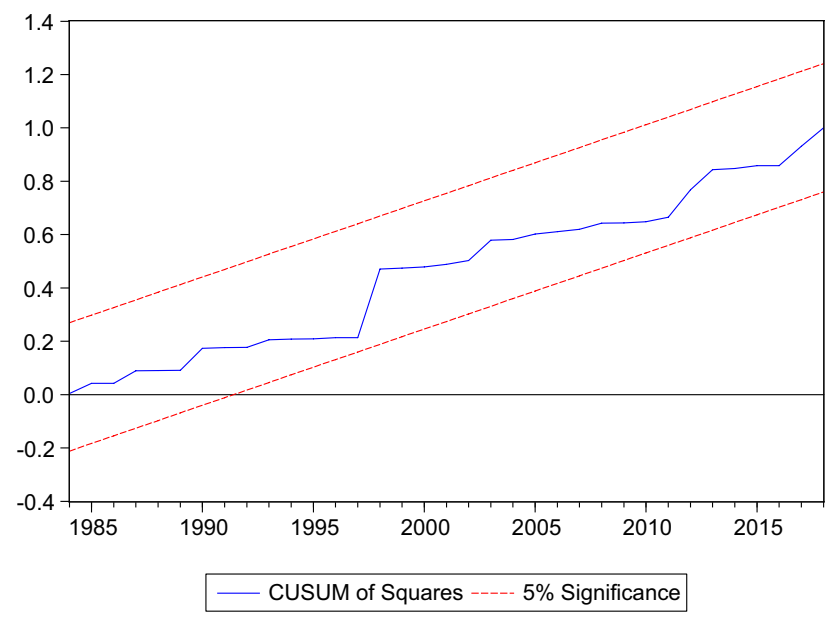

Fig. 7 CUSUM residual graphical plot for model 3 in Table 6 Source: Authors computation

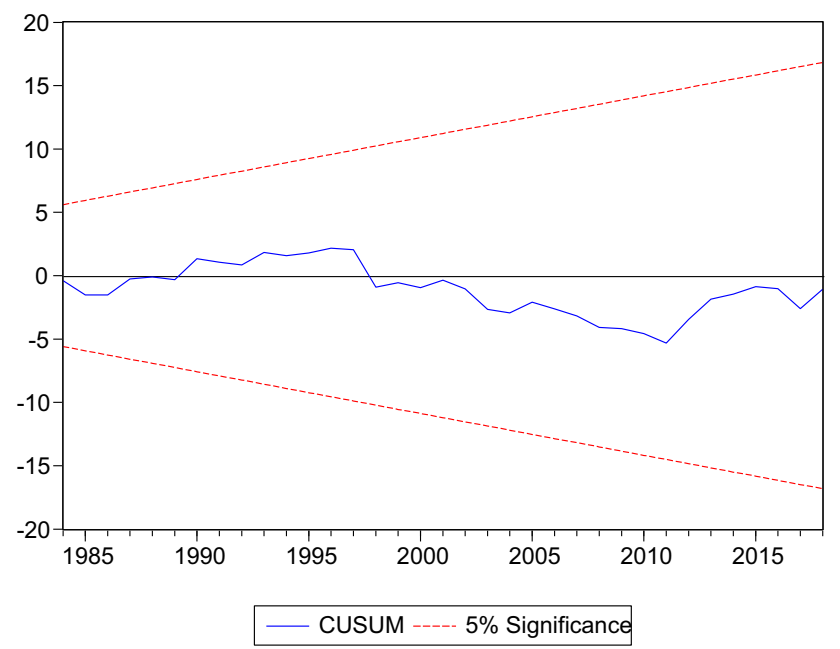

Fig. 8 CUSUM $^{2}$ residual graphical plot for model 1 in Table 6 Source: Authors computation

\section{Conclusion and policy implication}

Recently, Turkey's government embarks on two sensitive energy-related policies of coal expansion and consolidation of natural gas through construction of storage and regasification capacity. Considering the suspected aftermath effects of these policies on environment and economic performance, this study seeks to investigate the policy implication of the policies on Turkey's sustainability development. Author adopts Turkey's countryspecific data and series of 1974 to 2018 for effective investigation and justification of the findings of this study with emphasis on both short-run and long-run implications. Three models (two environment related and one economic) were applied to accommodate both environment and economic impacts. Ecological footprint was considered better and used as proxy for the environment related model. In congruence with literature and hypotheses, the results from cointegration estimation show that the twin polices may be good to the economic performance but will spark off dilapidated environment. Also, EKC was established for Turkey's environment and economic performance. In sum, with environment models, the selected series (per capita GDP, industrialization, agriculture, coal as a single energy use and mixed energy use) except per capita $\mathrm{GDP}^{2}$ were found positively and significantly related to ecological footprint in both short run and long run which translates to poor performance of Turkey's environment. Also, using economic growth model, the selected series (Industrialization, energy use, and agriculture) were all confirmed positively and significantly related to the economic growth (per capita GDP). Moreover, using Granger causality as robust check to these findings, a nexus was found among the series confirming the validity of the cointegartion (short and long run policies) estimations and results.

The findings of this study have important policy implications as they demonstrate that Turkey's economic performance is thriving at the expense of its environment. But with the establishment of EKC, it shows that the Turkey's economic growth/performance will cause a turning point in the economic growth and environment relationship, thereby ushering in a better environment performance. Based on this, it will be policy wise for Turkey as a country to continue to boost production of goods and services to raise GDP. With the attainment of certain level of economic growth, the country (Turkey) will achieve good environmental performance. In order to achieve this turning point without suspending the principle of EKC, a conscious and strict environmental regulations are needed to ensure the achievement of sustainable development. On the 
side of private establishments and firms, policies such as enactment of environmental laws by setting pollution limits with penalty of fine or increased tax on any violated firm, attracting clean and energy efficient technologies through industrialization and discouragement of over reliance on fossil fuels energy sources by adopting alternative (renewable) energy sources. However, on the side of the public authority, government should take ratification and implementation of Paris agreement serious by working towards reducing its emission to the acceptable level which is less than $2{ }^{\circ} \mathrm{C}$. Also, authority should reconsider and pursue with determined effort the Turkey's 2016 Renewable Energy Resource Area regulations projects, which is aimed at generating about $30 \%$ of its total electricity from renewable energy sources by 2023 . Authorities should set out and implement an integrated long-term energy and climate for a protracted period of time, say 2050 as basis for a sustainable development model. This will involve tracking and monitoring system, building upon the long-term goal. Turkey's government as a beneficiary of Clean Technology Fund (CTF) should utilize the opportunity and maximize the fund in innovating and accelerating her shift to a more renewable energy sources in order to achieve and maintain a clean nation with sustainable development.

The findings and policies recommended in this study have implications to the neighboring countries that are pursuing industrial and economic expansion without equivalent policy towards environment performance, and this study will aid their policy formulation with regard to their sustainable development goals.

Acknowledgements This manuscript has not been submitted to any journal for publication, nor is under review at another journal or other publishing venue

Author contribution The paper is written by a single author Edmund Ntom Udemba.

Availability of data and materials Data sources are outlined above in Table 1 and will be made available on demand.

\section{Declarations}

Ethics approval and consent to participate I, the author, is giving my ethical approval and consent for this paper to be published in your journal if found publishable.

Consent to participate I, the author, is giving my consent for participation in this paper to be published in your journal if found publishable.

Consent for publication I, the author, is giving my consent for this paper to be published in your journal if found publishable.

Competing interests The author declares no competing interests.

\section{References}

Ahmed K, Long W (2012) Environmental Kuznets curve and Pakistan: an empirical analysis. Procedia Economics and Finance 1:4-13

Akpan GE, Akpan UF (2012) Electricity consumption, carbon emissions and economic growth in Nigeria. International Journal of Energy Economics and Policy 2(4):292

Alam I, Quazi R (2003) Determinants of capital flight: an econometric case study of Bangladesh. Int Rev Appl Econ 17(1):85-103

Al-Mulali U, Tang CF, Ozturk I (2015a) Estimating the environment Kuznets curve hypothesis: evidence from Latin America and the Caribbean countries. Renew Sustain Energy Rev 50:918-924

Al-Mulali U, Weng-Wai C, Sheau-Ting L, Mohammed AH (2015b) Investigating the environmental Kuznets curve (EKC) hypothesis by utilizing the ecological footprint as an indicator of environmental degradation. Ecol Ind 48:315-323

Alola AA, Bekun FV, Sarkodie SA (2019) Dynamic impact of trade policy, economic growth, fertility rate, renewable and non-renewable energy consumption on ecological footprint in Europe. Sci Total Environ 685:702-709

Awokuse TO (2009) Does agriculture really matter for economic growth in developing countries? (No. 319-2016-9808)

Bagliani M, Galli A, Niccolucci V, Marchettini N (2008) Ecological footprint analysis applied to a sub-national area: the case of the Province of Siena (Italy). J Environ Manage 86(2):354-364

Bell J, Paula L, Dodd T, Németh S, Nanou C, Mega V, Campos P (2018) EU ambition to build the world's leading bioeconomyuncertain times demand innovative and sustainable solutions. New Biotechnol 40:25-30

Brown JH, Burnside WR, Davidson AD, DeLong JP, Dunn WC, Marcus J, Hamilton,Norman Mercado-Silva et al (2011) Energetic limits to economic growth. Bioscience 61(1):19-26

Cardoso A, Turhan E (2018) Examining new geographies of coal: dissenting energyscapes in Colombia and Turkey. Appl Energy 224:398-408

Carlson KM, Gerber JS, Mueller ND, Herrero M, MacDonald GK, Brauman KA et al (2017) Greenhouse gas emissions intensity of global croplands. Nat Clim Change 7(1):63-68

Chen Q J, Kong YF, Zhang HB (2006) Effect of coal mining on regional ecological footprint based on GIS. In: Geoinformatics 2006: GNSS and Integrated Geospatial Applications, vol 6418. International Society for Optics and Photonics, p 64181F

Cherniwchan J (2012) Economic growth, industrialization, and the environment. Resour Energy Econ 34(4):442-467

CIA, World-Factbook (2019) GDP composition by sector

Csereklyei Z, Thurner PW, Bauer A, Küchenhoff H (2016) The effect of economic growth, oil prices, and the benefits of reactor standardization: duration of nuclear power plant construction revisited. Energy Policy 91:49-59

Dickey DA, Fuller WA (1979) Distribution of the estimators for autoregressive time series with a unit root. J Am Stat Assoc 74(366a):427-431

Dogan N (2016) Agriculture and environmental kuznets curves in the case of Turkey: evidence from the ARDL and bounds test. Agric Econ 62(12):566-574

Dudu H, Çakmak EH (2018) Climate change and agriculture: an integrated approach to evaluate economy-wide effects for Turkey. Climate Dev 10(3):275-288

Duman AK, Özgen GÖ, Üçtuğ FG (2020) Environmental life cycle assessment of olive pomace utilization in Turkey. Sustainable Production and Consumption 22:126-137

Ediger VŞ, Berk I (2011) Crude oil import policy of Turkey: historical analysis of determinants and implications since 1968. Energy Policy 39(4):2132-2142 
El-Khozondar B (2017) Investigating the use of water for electricity generation at Turkish power plants (Master's thesis, Fen Bilimleri Enstitüsü)

Engle RF, Granger CW (1987) Co-integration and error correction: representation, estimation, and testing. Econometrica 55:251-276

Grimes P, Kentor J (2003) Exporting the greenhouse: foreign capital penetration and CO? Emissions 1980 1996. J World-Systems Res 261-275

Halicioglu F (2009) An econometric study of CO2 emissions, energy consumption, income and foreign trade in Turkey. Energy Policy 37(3):1156-1164

Hamilton LC, Keim BD (2009) Regional variation in perceptions about climate change. Int J Climatol 29(15):2348-2352

Hossain MS (2011) Panel estimation for CO2 emissions, energy consumption, economic growth, trade openness and urbanization of newly industrialized countries. Energy Policy 39(11):6991-6999

Johansen S (1988) Statistical analysis of cointegration vectors. J Econ Dyn Control 12(2-3):231-254

Johansen S, Juselius K (1990) Maximum likelihood estimation and inference on cointegration - with appucations to the demand for money. Oxford Bull Econ Stat 52(2):169-210

Katircioglu S, Gokmenoglu KK, Eren BM (2018) Testing the role of tourism development in ecological footprint quality: evidence from top 10 tourist destinations. Environ Sci Pollut Res 25(33):33611-33619

Kaya A, Tecmen A (2011) The role of common cultural heritage in external promotion of modern Turkey: Yunus Emre Cultural Centres

Kaya O, Kaya I, Gunter L (2012) Development aid to agriculture and economic growth. Rev Dev Econ 16(2):230-242

Kiliç FÇ, Kaya D (2007) Energy production, consumption, policies, and recent developments in Turkey. Renew Sustain Energy Rev 11(6):1312-1320

Kivyiro P, Arminen H (2014) Carbon dioxide emissions, energy consumption, economic growth, and foreign direct investment: causality analysis for Sub-Saharan Africa. Energy 74:595-606

Kuznets S (1955) Economic growth and income inequality. Am Econ Rev 45(March): 1-28

Kwiatkowski D, Phillips PC, Schmidt P, Shin Y (1992) Testing the null hypothesis of stationarity against the alternative of a unit root. $\mathrm{J}$ Econ 54(1-3):159-178

Li W, Sun S, Li H (2015) Decomposing the decoupling relationship between energy-related $\mathrm{CO}_{2}$ emissions and economic growth in China. Nat Hazards 79(2):977-997

Liu S, Zhao H, Lehmler HJ, Cai X, Chen J (2017a) Antibiotic pollution in marine food webs in Laizhou Bay, North China: trophodynamics and human exposure implication. Environ Sci Technol 51(4):2392-2400

Liu X, Zhang S, Bae J (2017b) The impact of renewable energy and agriculture on carbon dioxide emissions: investigating the environmental Kuznets curve in four selected ASEAN countries. J Clean Prod 164:1239-1247

Monje CA, Vinagre BM, Feliu V, Chen Y (2008) Tuning and autotuning of fractional order controllers for industry applications. Control Eng Pract 16(7):798-812

Narayan PK, Narayan S (2010) Carbon dioxide emissions and economic growth: panel data evidence from developing countries. Energy Policy 38(1):661-666

Neequaye NA, Oladi R (2015) Environment, growth, and FDI revisited. Int Rev Econ Financ 39:47-56

Network GF (2012) National footprint accounts, 2011th edn. Global Footprint Network, Oakland, CA, USA

Network GF (2018) Ecological footprint: Recuperado at https://www. footprintnetwork.org/our-work/ecological-footprint
Ohlan R (2016) Renewable and nonrenewable energy consumption and economic growth in India. Energy Sources, Part B: Economics, Planning, and Policy 11(11):1050-1054

Opoku EEO, Yan IKM (2019) Industrialization as driver of sustainable economic growth in Africa. J Int Trade Econ Dev 28(1):30-56

Opoku EEO, Boachie MK (2020) The environmental impact of industrialization and foreign direct investment. Energy Policy $137: 111178$

Ossadzifo K (2018) Industrialization and economic growth in subSaharan Africa: the role of human capital in structural transformation. J Empir Stud 5(1):45-54

Ozturk I, Al-Mulali U, Saboori B (2016) Investigating the environmental Kuznets curve hypothesis: the role of tourism and ecological footprint. Environ Sci Pollut Res 23(2):1916-1928

Panayotou T (1993) Empirical tests and policy analysis of environmental degradation at different stages of economic development (No. 992927783402676). International Labor Organization

Pao HT, Tsai CM (2011) Modeling and forecasting the CO2 emissions, energy consumption, and economic growth in Brazil. Energy 36(5):2450-2458

Perron $\mathrm{P}$ (1990) Testing for a unit root in a time series with a changing mean. J Bus Econ Stat 8(2):153-162

Pesaran MH, Shin Y (1998) An autoregressive distributed-lag modelling approach to cointegration analysis. Econom Soc Monogr 31:371-413

Pesaran MH, Shin Y, Smith RJ (2001) Bounds testing approaches to the analysis of level relationships. J Appl Economet 16(3):289-326

Petroleum B (2019) BP Statistical Review of World Energy Report. UK, BP, London

Raza SA, Shah N, Sharif A (2019) Time frequency relationship between energy consumption, economic growth and environmental degradation in the United States: Evidence from transportation sector. Energy 173:706-720

Reckien D, Salvia M, Heidrich O, Church JM, Pietrapertosa F, de Gregorio-Hurtado $\mathrm{S}$ et al (2018) How are cities planning to respond to climate change? Assessment of local climate plans from 885 cities in the EU-28. J Clean Prod 191:207-219

Rees W, Wackernagel M, Testemale P (1996) Our ecological footprint: reducing human impact on the Earth. New Society Publishers, Gabriola Island, BC, pp 3-12

Roubini N, Setser B (2004) Bailouts or bail-ins?: responding to financial crises in emerging economies. Peterson Institute

Sarkodie SA, Strezov V (2019) Effect of foreign direct investments, economic development and energy consumption on greenhouse gas emissions in developing countries. Sci Total Environ 646:862-871

Shafik N, Bandyopadhyay S (1992) Economic growth and environmental quality: time series and cross section evidence. Policy research working paper $\mathrm{N}^{\circ}$ WPS904, World Bank

Shahbaz M, Nasreen S, Ahmed K, Hammoudeh S (2017) Trade openness-carbon emissions nexus: the importance of turning points of trade openness for countrypanels. Energy Econ 61:221-232

Siddiqui R (2004) Energy and economic growth in Pakistan. The Pakistan Development Review 175-200

Solarin SA, Bello MO (2018) Persistence of policy shocks to an environmental degradation index: the case of ecological footprint in 128 developed and developing countries. Ecol Ind 89:35-44

Song HJ, Lee S, Park K, Lee J, Chand Spah D, Park JW, Filburn TP (2008) Simplified estimation of regeneration energy of $30 \mathrm{wt} \%$ sodium glycinate solutionfor carbon dioxide absorption. Ind Eng Chem Res 47(24):9925-9930

Tao S, Zheng T, Lianjun T (2008) An empirical test of the environmental Kuznets curve in China: a panel cointegration approach. China Econ Rev 19(3):381-392 
Tracker CA (2019) The CAT thermometer. Climate crisis demands more government action as emissions rise. Online verfügbar unter. https://climateactiontracker.org/global/cat-thermometer/

Tsakok I, Gardner B (2007) Agriculture in economic development: primary engine of growth or chicken and egg? Am J Agric Econ 89(5):1145-1151

Uddin GA, Salahuddin M, Alam K, Gow J (2017) Ecological footprint and real income: Panel data evidence from the 27 highest emitting countries. Ecol Ind 77:166-175

Ulucak R, Lin D (2017) Persistence of policy shocks to Ecological Footprint of the USA. Ecol Ind 80:337-343

Veyisoglu A, Carro L, Guven K, Cetin D, Spröer C, Schumann P et al (2016) Micromonospora yasonensis sp. nov., isolated from a Black Sea sediment. Antonie van Leeuwenhoek 109(7):1019-1028

Waldman S, Caliskan E (2017) The New Turkey and its discontents. Oxford University Press

Wang KM (2012) Modelling the nonlinear relationship between $\mathrm{CO} 2$ emissions from oil and economic growth. Econ Model 29(5):1537-1547

Wang L, Wei SP, Wang QJ (2008) Effect of coal exploitation on groundwater and vegetation in the Yushenfu Coal Mine. J China Coal Soc 33(12):1408-1414
Wang Y, Kang L, Wu X, Xiao Y (2013) Estimating the environmental Kuznets curve for ecological footprint at the global level: a spatial econometric approach. Ecol Ind 34:15-21

WDI T (2019) World development indicators (DataBank)

Xu B, Lin B (2015) Factors affecting carbon dioxide (CO2) emissions in China's transport sector: a dynamic nonparametric additive regression model. J Clean Prod 101:311-322

Yavuz F, Bilgic A, Terin M, Guler IO (2013) Policy implications of trends in Turkey's meat sector with respect to 2023 vision. Meat Sci 95(4):798-804

Yu-ming WU (2010) Kuznets curve analysis of guangxi ecological footprint and energy consumption. China Popul Resour Environ 20(11):30-35

Publisher's note Springer Nature remains neutral with regard to jurisdictional claims in published maps and institutional affiliations. 